\title{
PEMBERDAYAAN MASYARAKAT MELALUI KELOMPOK SWABANTU DALAM MENGELOLA SAMPAH MENJ ADI APE ANAK USIA DINI
}

\author{
Sarciani Suhartini Kase ${ }^{1 *}$, Kurniawan Erman Wicaksono ${ }^{2}$, Mizam Ari Kurniyanti ${ }^{3}$
}

${ }^{1}$ STIKES Widyagama Husada

${ }^{2}$ STIKES Widyagama Husada

${ }^{3}$ STIKES Widyagama Husada

Corresponding author:

Kurniawan Erman Wicaksono

STIKES Widyagama Husada

Email:wicaksono42137@ gmail.com

\begin{abstract}
Waste in the most common problem in the world, not only in developin countries but also in developed countries. Waste has always been a major problem. Good knowledge of waste management followed by the attitude of parent's who support waste management as an educational game tool is one ay to solve the waste problem. Community empoerment activities in managing waste are very helpful in overcoming waste volume accumulation. Knowing the effect of community empowerment through self-help groups on the knowledge and attitudes of parents in waste management becomes an Educational Game Tool. The study used a pre-experimental design with one group pre-test and postest approaches given to 24 respondent. The level of knowledge and attitudes in managing waste into an educational game was obtained by e questionnaire. The statistical test used Wilcoxon. The results of the bivariate analysis obtained $p=0.002$ which showed that there is an effect of community empowerment through self-help groups on the knowledge and attitudes of parents in processing waste into educational games. This study shows that before the waste management extension intervention was carried, 3 respondents were categorized as sufficient in attitude. And after being given the intervention, 24 respondent got a god category in knowledge, and 21 respondent were in a good category in attitude. Counseling on waste management (recycling) should be carried out regularly to assist the community in reducing waste accumulation, knowledge and attitudes in managing waste.
\end{abstract}

Keywords: Knowledge; Attitudes; Community Empowermen;Self Help Groups.

\section{Abstrak}

Sampah merupakan masalah yang paling banyak terjadi didunia, bukan hanya di Negara berkembang tetapi juga di negara-negara maju sampah selalu menjadi permasalah utama. Pengetahuan yang bagus terhadap pengelolaan sampah diikuti dengan sikap orangtua yang mendukung pengelolaan sampah menjadi Alat Permainan edukatif (APE) adalah salah satu cara untuk mengatasi masalah sampah. Kegiatan pemberdayaan masyarakat dalam mengelolah sampah sangat membantu dalam menanggulangi penumpukan volume sampah. Mengetahui pengaruh pemberdayaan masyarakat melalui kelompok swabantu terhadap pengetahuan dan sikap orangtua dalam pengelolaan sampah menjadi Alat Permainan Edukatif (APE) anak usia dini. Penelitian ini menggunakan desain praeksperimen dengan pendekatan one group pre test dan post test yang diberikan kepada 24 responden. Tingkat pengetahuan dan sikap dalam mengelolah sampah menjadi alat permainan edukatif diperoleh dengan kuesioner Uji statistik yang digunakan adalah wilcoxon. Hasil analisa bivariat didapatkan $p=0.002$ yang menunjukan terdapat pengaruh pemberdayaan masyarakat melalui kelompok swabantu terhadap pengetahuan dan sikap orangtua dalam mengelolah sampah menjadi alat permainan edukatif. Penelitian ini menunjukan sebelum dilakukan intervensi penyuluhan pengelolaan sampah 3 responden mendapat kategori cukup dalam pengetahuan, dan 4 responden kategori cukup dalam sikap. Dan setelah diberikan intervensi 24 responden mendapat kategori baik dalam pengetahuan, dan 21 responden kategori baik dalam sikap. Penyuluhan pengelolaan sampah (daur ulang) sebaiknya dilakukan secara 
rutin untuk membantu masyarakat dalam mengurangi penumpukan sampah, dan dapat meningkatkan pengetahuan dan sikap masyarakat dalam mengelolah sampah.

Kata Kunci: Pengetahuan; Sikap; Pemberdayaan masyarakat; Kelompok Swabantu. 


\section{PENDAHULUAN}

Sampah merupakan masalah yang paling banyak terjadi didunia, bukan hanya di negara berkembang tetapi juga di negara-negara maju sampah selalu menjadi permasalah utama. Pengetahuan yang bagus terhadap pengelolaan sampah diikuti dengan sikap orangtua yang mendukung pengelolaan sampah menjadi Alat Permainan edukatif (APE) adalah salah satu cara untuk mengatasi masalah sampah di RW 02 Kelurahan Merjosari Kota Malang. Kegiatan pemberdayaan masyarakat dalam mengelolah sampah sangat membantu dalam menanggulangi penumpukan volume sampah.

Penelitian ini bertujuan untuk mengetahui pengetahuan dan sikap orangtua melalui pemberdayaan masyarakat dalam mengelolah sampah menjai alat permainan edukatif anak usia dini. Kementerian lingkungan hidup melakukan upaya pengembangan Bank Sampah. Kegiatan ini bersifat sosial engineering yang mengajarkan masyarakat untuk memilah sampah, sekaligus menumbuhkan kesadaran masyarakat dalam pengelolaan sampah secara bijak. Salah satu teknik sampah yang dapat diolah yaitu menjadi Alat Permainan Edukatif (APE) untuk anak usia dini. Peran serta masyarakat dalam mengkategorikasikan barang bekas dapat dijadikan sumber informasi dan penyedia barang bekas untuk kebutuhan sekolah dalam pengadaan media pembelajaran.

Melihat upaya ini dapat disimpulkan bahwa peran serta masyarakat dalam pembangunan merupakan faktor yang sangat penting. Partisipasi masyarakat dalam pengelolaan sampah dapat meningkatkan kesadaran masyarakat akan pentingnya kebersihan lingkungan yang hijau, bersih dan sehat serta menguatkan inisiatif masyarakat dalam menjaja, memelihara dan meningkatkan fungsi lingkungan. Disamping itu, kemampuan masyarakat berkontribusi dalam pengelolaan sampah juga akan sangat tergantung kepada pendapatan masyarakat, khusunya di RW 02 Kelurahan Merjosari Kota Malang.

\section{METODE}

Penelitian ini menggunakan desain praeksperimen dengan pendekatan one group pre test dan post test yang diberikan kepada 24 responden. Tingkat pengetahuan dan sikap dalam mengelolah sampah menjadi alat permainan edukatif diperoleh dengan kuesioner Uji statistik yang digunakan adalah wilcoxon. Penelitian menggunakan kuesioner sebanyak 2 kuesioner yakni pengetahuan dan sikap yang telah dilakukan uji validitas dan reliabilitas.

\section{HASIL DAN PEMBAHASAN}

Table 1. Karakteristik Usia Responden

\begin{tabular}{ccc}
\hline $\begin{array}{c}\text { Usia } \\
\text { responden }\end{array}$ & N & Presentase \\
\hline $27-28$ tahun & 9 & 37,5 \\
$29-30$ tahun & 7 & 29,1 \\
$>30$ tahun & 8 & 33,3 \\
Total & 24 & 100,0 \\
\hline
\end{tabular}

Tabel 1 menunjukkan hasil analisis karakteristik responden berdasarkan usia. Responden yang berusia 27 tahun sebanyak 9 (37,5\%) responden, responden yang berusia 29 tahun sebanyak $7(29,1 \%)$ responden, responden yang berusia lebih dari 30 tahun sebanyak $8(33,3 \%)$ responden.

Tabel 2. Karakteristik Pendidikan Responden

\begin{tabular}{ccc}
\hline $\begin{array}{c}\text { Jenis } \\
\text { Kelamin }\end{array}$ & $\mathbf{N}$ & Presentase \\
\hline SD & 0 & 0 \\
SMP & 9 & 37.5 \\
SMA & 13 & 45.8 \\
PT & 2 & 8,3 \\
& & 100,0 \\
\hline
\end{tabular}


Tabel 2 menunjukkan hasil analisis karakteristik responden berdasarkantingkat pendidikan Responden dengan tingkat pendidikan SD $0 \quad(0 \%)$ responden, responden dengan tingkat pendidikan SMP $9(37,5 \%)$ responden, responden dengan tingkat pendidikan SMA $11 \quad(45,8 \%)$ responden, responden dengan tingkat pendidikan sarjana $2(8,3 \%)$. Sebelum dan setelah diberikan intervensi peneliti mengukur tingkat pengetahuan pengelolaan sampah menjadi alat permainan edukatif dengan menggunakan kuesioner. Hasil kuesioner dianalisa menggunakan uji SPSS Wilcoxon

Tabel 3. Hasil Uji Tingkat Pengetahuan Pengelolaan Sampah Menjadi APE Sebelum Dan Sesudah Dilakukan Pendidikan Kesehatan Penyuluhan Pengelolaan Sampah Menjadi APE

\begin{tabular}{llllll}
\hline \multicolumn{1}{c}{$\begin{array}{c}\text { Tingkat } \\
\text { Pengetahuan }\end{array}$} & \multicolumn{2}{c}{ Sebelum } & \multicolumn{2}{c}{ Sesudah } & $\begin{array}{l}\text { Signifi } \\
\text { kansi }\end{array}$ \\
\cline { 2 - 6 } & $\begin{array}{l}\text { Freku } \\
\text { ensi }\end{array}$ & $\begin{array}{l}\text { Presen } \\
\text { tase }\end{array}$ & $\begin{array}{l}\text { Freku } \\
\text { ensi }\end{array}$ & $\begin{array}{l}\text { Presen } \\
\text { tase }\end{array}$ \\
Kurang & 0 & 0 & 0 & 0 & 0,000 \\
Cukup & 3 & 12,5 & 0 & 0 & \\
Baik & 21 & 87,5 & 24 & 100 & \\
Total & 24 & 100,0 & 24 & 100,0 & \\
\hline
\end{tabular}

Dasar pengambilan hipotesis adalah jika nilai Asymp Sign $<0.05$ maka hipotesis dapat diterima. Dan hasil uji nilai Asymp Signpada pretest dan posttest pengelolaan sampah menjadi APE adalah 0.000. 0.000 $<0.05$ berarti dapat disimpulkan bahwa hipotesis diterima. Artinya ada perbedaan antara hasil uji kuesioner pengetahuan untuk Pretest dan Posttest.Sehingga dapat disimpulkan bahwa "ada pengaruh pemberdayaan masyarakat melalui kelompok swabantu terhadap pengetahuan dan sikap orangtua dalam mengelola sampah menjadi alat permainan edukatif anak usia dini”.

Tabel 4. Hasil Uji Tingkat Sikap Pengelolaan Sampah Menjadi APE Sebelum Dan Sesudah Dilakukan Pendidikan Kesehatan Penyuluhan Pengelolaan Sampah Menjadi APE

\begin{tabular}{llllll}
\hline Tingkat sikap & \multicolumn{2}{c}{ Sebelum } & \multicolumn{2}{c}{ Sesudah } & $\begin{array}{l}\text { Signifi } \\
\text { kansi }\end{array}$ \\
\cline { 2 - 6 } & $\begin{array}{l}\text { Freku } \\
\text { ensi }\end{array}$ & $\begin{array}{l}\text { Present } \\
\text { ase }\end{array}$ & $\begin{array}{l}\text { Freku } \\
\text { ensi }\end{array}$ & $\begin{array}{l}\text { Present } \\
\text { ase }\end{array}$ & \\
Kurang & 0 & 0 & 0 & 0 & 0,002 \\
Cukup & 4 & 16,6 & 3 & 12,5 & \\
Baik & 20 & 83,3 & 21 & 87,5 & \\
Total & 24 & 100,0 & 24 & 100,0 & \\
& & & & & \\
\hline
\end{tabular}

Dasar pengambilan hipotesis adalah jika nilai Asymp Sign $<0.05$ maka hipotesis dapat diterima. Dan hasil uji nilai Asymp Sign pada pretest dan posttest sikap responden dalam pengelolaan sampah menjadi APE adalah 0.002. $0.002<0.05$ berarti dapat disimpulkan bahwa hipotesis diterima.Artinya ada perbedaan antara hasil uji kuesioner sikap untuk Pretest dan Posttest. Sehingga dapat disimpulkan bahwa "ada pengaruh pemberdayaan masyarakat melalui kelompok swabantu terhadap pengetahuan dan sikap orangtua dalam mengelola sampah menjadi alat permainan edukatif anak usia dini". Hasil atas bahwa hasil Uji Wilcoxon signifikan 0,000,dan 0.002 karena nilai $\mathrm{p}<0,05$ secara statistika terdapat perbedaan pengetahuan yang bermakna.

Peneliti memberikan intervensi berupa pemberdayaan masyarakat melalui kelompok swabantu. Peneliti melakukan penyuluhan dimana penyuluhan diberikan berupa video lewat online terkait bagaimana pengelolaan sampah menjadi APE. Sebelum dan sesudah diberikan intervensi penyuluhan, peneliti melakukan pengukuran tingkat pengetahuan dan sikap responden menggunakan kuesioner sebagai alat ukur. Hasil dari kuesioner tersebut kemudian dianalisa untuk mengetahui perbedaan antara tingkat pengetahuan dan sikap responden sebelum dan sesudah diberikan intervensi dengan menggunakan uji wilcoxon. Hasil Tabel 3 dan 4 di atas bahwa hasil Uji Wilcoxon signifikan 0,000, 
dan 0,002 karena nilai $\mathrm{p}<0,05$ secara statistika terdapat perbedaan pengetahuan yang bermakna.

\section{KESIMPULAN}

Hasil penelitian ini menunjukkan bahwa Terdapat pengaruh pemberdayaan masyarakat melalui kelompok swabantu terhadap pengetahuan dan sikap orangtua dalam mengelolah sampah menjadi alat permainan edukatif anak usia dini. $\mathrm{p}=0,002(\mathrm{p}<0,05)$ pengetahuan, dan $\mathrm{p}=0,005(\mathrm{p}<0,05)$ sikap.

\section{UCAPAN TERIMA KASIH}

Ucapan terimakasih diberikan kepada seluruh pihak yang telah membantu dalam proses penelitian maupun terbitan artikel. Semoga artikel dan penelitian ini dapat bermanfaat bagi pembaca maupun peneliti selanjutnya.

\section{DAFTAR RUJUKAN}

Arifin, R., \& Sri, S. (2016). Hubungan Tingkat Pengetahuan Ibu Tentang Kebutuhan Gizi Ibu Hamil Dengan Status Gizi Ibu Hamil Di Puskesmas Pleret Bantul. Universitas Muhammadiyah Yogyakarta, 9-29.

Azwar. (2013). Sikap Manusia Teori dan Pengukurannya. Pustaka Pelajar. Yogyakarta. $1-26$.

Budiaji, W. (2013). Skala Pengukuran dan Jumlah Respon Skala Likert (The Measurement Scale and The Number of Responses in Likert Scale). Ilmu Pertanian Dan Perikanan, 2(2), 127-133.

EU. (2008). EU Waste Management Law. Eu2, (December 2008), 11-12. Retrieved from http://eur-lex.europa.eu/legalcontent/EN/TXT/?qid=1455646434895\&uri= URISERV:ev0010

Fauziddin, M., \& Mufarizuddin, M. (2018). Useful of Clap Hand Games for Optimalize Cogtivite Aspects in Early Childhood Education. Jurnal Obsesi: Jurnal Pendidikan Anak Usia Dini, 2(2), 162. https://doi.org/10.31004/obsesi.v2i2.76

Ii, B. A. B., \& Pustaka, T. (2007). Bab II Tinjauan Pustaka Mammografi. 5-18.

Ii, B. A. B., \& Sikap, A. (2016). Sikap Santri Terhadap..., Nurul Mahmudah, Fakultas Psikologi UMP, 2016. (2009).

Ilmiah, K. T., Keperawatan, S., \& Muhammadiyah, U. (2010). Pengaruh Kelompok Swabantu ( Self Help Group ) Terhadap Tingkat Stres Orangtua Dengan Anak Retardasi Mental Di Slb Negeri 3 Yogyakarta. 3-5.

Khasanah, I., Djariyo, D., Damayani, A. T., \& Mushafanah, Q. (2013). Pemanfaatan Lingkungan Dan Barang Bekas Sebagai Alat Permainan Edukatif (Ape) Bagi Kader Pos Paud Kelurahan Tambak Rejo Semarang. E-Dimas, $4(2), \quad 24 . \quad$ https://doi.org/10.26877/edimas.v4i2.1565

Cite this article as: Kase, Sarciani Suhartini. dkk.(2020). Pemberdayaan Masyarakat Melalui Kelompok Swabantu Dalam Mengelola Sampah Menjadi Ape Anak Usia Dini. Media Husada Journal of Nursing Science. Vol. 1(No.1), 5458. https://doi.org/10.33475/mhjns.vdiisi tim redaksi.. 